DOI https://doi.org/10.30525/978-9934-588-92-1-74

\title{
ПИТАННЯ КРИМІНАЛЬНО-ПРАВОВОГО ХАРАКТЕРУ ЩОДО ОКРЕМИХ КРИМІНАЛЬНИХ ПРАВОПОРУШЕНЬ ПРОТИ ПРАВОСУДДЯ
}

\author{
Воронцов А. В. \\ дочент кафедри кримінального права та кримінології \\ факультету підготовки фахівців для органів досудового розслідування \\ Одеського державного університету внутрішніх справ \\ м. Одеса, Украӥна
}

Проблеми конкретизації i вдосконалення кримінального законодавства та окремих ії норм завжди актуально. Одним з головних аспектів кримінальних правопорушень, що посягають на охоронювані законом права та інтереси громадян, якими вони наділені як учасники або інші суб'єкти кримінального або цивільного процесу $\epsilon$ конкретизація безпосереднього об'єкта. Вважається, що найбільш вдалою є класифікація кримінальних правопорушень проти правосуддя за їх безпосередніх об'єктах, оскільки вони найбільшою мірою відображають ті змінення які відбуваються у державі та суспільстві. Загальновизнаним положенням $є$ те, що «місце конкретної кримінально-правової норми у законодавстві про кримінальну відповідальність визначається 3 урахуванням захисту не тільки родового, а й основного безпосереднього об'єкта досліджуваного складу кримінального правопорушення (злочину). Натомість, додатковим безпосереднім об'єктом є суспільні відносини, яким шкода завдається завжди» [6, с. 70-74]. Звертаючи увагу на це питання необхідно підкреслити суспільну небезпечність (яка насамперед $\epsilon$ складовою ознакою загального поняття кримінального правопорушення) кримінальних правопорушень проти правосуддя, які вчиняються службовими особами органів досудового розслідування, порушуючи тим самим конституційні права людини та громадянина [1, ст. 3].

Що ж є за своєю сутністю суспільна небезпечність?

3 загальної доктрини права суспільна небезпечність $є$ посягання на важливі цінності та блага суспільства, умови його існування. Поряд 3 цим існує i інша підхід щодо інтерпретації поняття суспільної небезпечності.

3 кримінально-правової точки зору суспільна небезпечність - це основна матеріальна ознака кримінального правопорушення, яка розкриває його матеріальний зміст. 
Вона полягає в тому, що це діяння завдає або складає загрозу завдати істотну шкоду об'єктам кримінально-правової охорони - суспільним відносинам (цінностям, благам). У ньому виявляється негативне ставлення особи до таких об'єктів, а іноді в цілому до панівних у суспільстві відносин. Перелік цих відносин міститься у ст. 1 КК України: права і свободи людини і громадянина, власність, громадський порядок та громадська безпека, довкілля, конституційний устрій України від кримінально-правових посягань, забезпечення миру і безпека людства, а також запобігання кримінальним правопорушенням. Перелік суспільних відносин конкретизується і доповнюється у статтях Особливої частини КК. Суспільна небезпечність кримінальних правопорушень являє собою критерієм розділення на їх різновиди [2].

Суспільна небезпечність діяння - об'єктивна властивість будь-якого правопорушення, включаючи й кримінальне. Кримінальним правопорушенням суспільно небезпечне діяння стає, тоді коли ступінь i характер його небезпечності для певних у суспільстві відносин змушують законодавця вести 3 ним боротьбу кримінально-правовими заходами, тобто коли законом про кримінальну відповідальність воно визнається кримінальним правопорушенням [3, с. 93].

На протязі історичного розвитку суспільства $є$ чимало прикладів прояву суспільної небезпечності визначених кримінальних правопорушень. Одним з яскравих прикладів - це період «сталінських репресій». Вперше про них стало відомо у 1956 році. В доповіді на XX з'їзді КПРС Микита Хрущов розповів про те, що Сталін і група прибічників до нього членів Політбюро не тільки ідеологічно обгрунтовували та планували репресивні операції, але й “вершили правосуддя" безпосередньо: виносили заочно розстрільні вироки за списками, підготовленими НКВС і не містили ніякої інформації про арештованих, ні про винесені їм обвинувачення - тільки прізвища, ім'я, по батькові та додатки про міру покарання. Таким чином, тільки у другі половині 1930 -х років на розстріл та у табори було відправлено понад 40 тис. людей [5].

Захист кримінально-правовими засобами від визначених посягань забезпечує існування та охорону конституційного права на свободу та особисту недоторканність [1, ст. 3].

Сутністю суспільної небезпечності кримінальних правопорушень проти правосуддя, що вчинюються службовими особами органів досудового розслідування є його посягання на об'єкти, що охороняються законом, у ньому (діянні - дії або бездіяльності) виявляється негативне до них ставлення. 
Законодавець визнає кримінальним правопорушенням не самі по собі об'єктивні суспільно-небезпечні діяння, а дії вольові (завідомо незаконні затримання, привід, домашній арешт або тримання під ватою, притягнення завідомо невинного до кримінальної відповідальності, примушування давати показання та порушення права на захист) [4, с. 417-429], тобто такі, що знаходяться під контролем свідомості та волі особи, - дії винні. При цьому від суб'єктивних ознак залежить не тільки ступень суспільної небезпечності діяння, а насамперед визначення самого діяння суспільно небезпечним.

Щодо розкриття змісту поняття "ступінь суспільної небезпечності" використовується поняття “характер суспільної небезпечності”. Якщо ступінь суспільної небезпечності $є$ показником рівня небезпечності окремо взятих, конкретних діянь, їх “кількісні” характеристики, то характер суспільної небезпечності - це показник рівня суспільної небезпечності кримінальних правопорушень, що посягають на охоронювані законом права та інтереси громадян, якими вони наділені як учасники або інші суб'єкти кримінального або цивільного процесу який визначається, насамперед, місцем цінностей та благ, на які посягає ця група кримінальних правопорушень, у ієрархії цінностей, що $є$ об'єктом кримінально-правової охорони.

У процесі застосування ст.ст. 371-374 КК України суспільна небезпечність $\epsilon$ критерієм: 1) кваліфікації кримінальних правопорушень (відмежування їх від інших правопорушень; відмежування кримінальних правопорушень від інших діянь, що через мало значущість не $\epsilon$ суспільно небезпечними; розмежування їх як таких); 2) індивідуалізація кримінальної відповідальності та покарання [3, с. 99-102].

При цьому показником рівня суспільної небезпечності кримінальних правопорушень $\epsilon$ (має бути) санкція визначених статей (частини, пункту статті) Кримінального кодексу і з розвитком суспільства та законодавства кримінальні правопорушення, що посягають на охоронювані законом права та інтереси громадян, якими вони наділені як учасники або інші суб'єкти кримінального або цивільного процесу все більше потребують вдосконалення і конкретизації, не тільки їх суспільна небезпека, але ї інші обставини кримінально-правового характеру.

Отже, держава повинна здійснювати всі передбачені законом дії щодо поновлення порушених прав і свобод людини та громадянина.

\section{Література:}

1. Конституція України. URL: http://zakon.rada.gov.ua

2. Кримінальний кодекс. URL: http://zakon.rada.gov.ua 
3. Кримінальне право України: Загальна частина: підручник / С. В. Албул, А. М. Бабенко, А. В. Воронцов, та ін.; за ред. д.ю.н., проф. О. В. Меркулової, д.ю.н. доцента В. Я. Конопельського. Одеса : ОДУВС, 2017. $432 \mathrm{c.}$

4. Науково-практичний коментар Кримінального кодексу України [текст] / За заг. ред. Литвинова О. М. К. : «Центр учбової літератури», 2017. $528 \mathrm{c}$.

5. Сталінські репресії. URL: https://uk.wikipedia.org/wiki

6. Таций В. Я. Объект и предмет преступления в Советском уголовном праве. Харьков : Высшая школа, 1988. 198 с.

DOI https://doi.org/10.30525/978-9934-588-92-1-75

\title{
ЩОДО ВИЗНАЧЕННЯ ОБ'СКТА ЗАПОБІГАННЯ ЗЛОЧИННОСТІ
}

\author{
Лукашевич С. Ю. \\ кандидат юридичних наук, дочент, \\ дочент кафедри кримінології та кримінально-виконавчого права \\ Начіонального юридичного університету імені Ярослава Мудрого \\ м. Харків, Украӥна
}

Поняття об'єкта запобігання злочинності з'явилося у кримінології порівняно недавно, адже за радянських часів спеціальних досліджень із цієї проблематики не проводилось. Навіть у фундаментальних роботах проблема визначення об'єкту запобігання злочинності фактично не розглядалась, хоча очевидно, що вона була і залишається ключовою 3 точки зору ідеології, політики, стратегії і тактики відповідної діяльності.

Внаслідок невирішеності цієї проблеми в кримінології мають місце суперечливі судження з приводу сутності, змісту та об'єму поняття «об'єкт запобігання злочинності». Спостерігається ситуація, коли різні автори одне й те саме явище називають або об'єктом, або предметом, а окремі - розглядають об'єкт і предмет як тотожність, або як категорії, що мають непринципові термінологічні відмінності. На цій основі склалась ситуація, коли, наприклад, протиріччя у суспільних відносинах називають предметом, а наслідки цих протиріч криміногенні фактори - об'єктом протидії злочинності. Слід 